\title{
Response of Integrated Nutrient Management on Soil Properties, Growth and Yield of Cluster Bean (Cyamopsis tetragonoloba L.) Cv. Pusa Sadabahar
}

\author{
Asha*, Narendra Swaroop and Tarence Thomas \\ Department of Soil Science and Agricultural Chemistry, Sam Higginbottom University of \\ Agriculture, Technology and Sciences, Allahabad, 211007 U. P., India \\ *Corresponding author
}

\section{A B S T R A C T}

\section{Keywords}

Soil nutrients, yield attributes, FYM, rhizobium, NPK and Cluster bean

Article Info

Accepted:

25 April 2017

Available Online:

10 May 2017
An experiment was conducted during Kharif (july-october) season 2016-17 to study "Response of Integrated Nutrient Management on Soil Properties, Growth and Yield of Cluster bean (Cyamopsis tetragonoloba L.) Cv. Pusa Sadabahar" on central research farm of Sam Higginbottom University of Agriculture, Technology and Sciences Allahabad. The soil of experimental area falls in order Inceptisol and soil texture was sandy loam (sand \% 62.25, silt \% 24.52 and clay \% 13.23). The design applied for statistical analysis was carried out with $3 \times 2 \times 2$ factorial randomized block design having three factors with three levels of NPK @ 0, 50, and 100\% ha ${ }^{-1}$, two levels of FYM @ 0 and 100\% ha-1and two level of rhizobium @ 0 and 100\% respectively. The best treatment was T11 - [L2 F1 Z1] (@100\% NPK ha ${ }^{-1}+100 \% \mathrm{FYM} \mathrm{ha}^{-1}+100 \%$ rhizobium) showed the significant increase on enrichment of soil fertility status. NPK, FYM and rhizobium in combination resulted in a slight decrease in $\mathrm{pH} 6.89$, EC $0.225 \mathrm{dS} \mathrm{m}^{-1}$. In post soil of NPK,FYM and rhizobium fertilizers observations were resulted in significant increase in organic carbon $0.88 \%$, particle density $2.66 \mathrm{Mg} \mathrm{m}^{-3}$, bulk density $1.05 \mathrm{Mg} \mathrm{m}^{-3}$ and available $\mathrm{N} 334.12 \mathrm{~kg} \mathrm{ha}^{-1}$, available P $34.76 \mathrm{~kg} \mathrm{ha}^{-1}$, available $\mathrm{K} 214.74 \mathrm{~kg} \mathrm{ha}^{-1}$. Significant increase in case of nitrogen, phosphorus, potassium in treatment combination T11 -[L2F1 Z1] (@100\% NPK $\mathrm{ha}^{-1}+$ @ 100\% FYM ha ${ }^{-1}+$ @ 100\% rhizobium). The maximum cost benefit ratio was recorded 1:2.85 in treatment combination [T11 - L2 F1 Z1] (@100\% NPK ha ${ }^{-1}+0 \%$ FYM ha $^{-1}+100 \%$ rhizobium) and maximum net return (100438 ha-1) and highest pod yield (77.22 q ha $\left.{ }^{-1}\right)$ in treatment combination [T11 - L2 F1 Z1] (@ 100\% NPK ha ${ }^{-1}+$ $100 \%$ FYM ha $^{-1}+100 \%$ rhizobium).

\section{Introduction}

Cluster bean [Cyamopsis tetragonoloba (L.) Taub] popularly known as "Guar" is an important legume crop mainly grown under rainfed condition in arid and semi-regions of Rajasthan during kharif season. It is very hardy and drought tolerant crop. Its deep penetrating roots enable the plant to utilize available moisture more efficiently and thus offer better scope for rainfed cropping. The crop also survives even at moderate salinity and alkalinity conditions. There is no other legume crop so hardy and drought tolerant as cluster bean (Kherawat et al., 2013).

In India, cluster bean is mostly grown in Rajasthan, Haryana, Punjab, Uttar Pradesh and Madhya Pradesh. Rajasthan occupies first position in India both in area and production. 
It accounts for almost $82.1 \%$ area and $70 \%$ production in India. Haryana and Gujarat has second and third position respectively. Rajasthan has an area of 30 lakh ha, production of 15.46 lakh tonnes with a productivity of $515 \mathrm{~kg} \mathrm{ha}^{-1}$. (Anonymous 2010-11). Rajasthan guar is mainly grown in Barmer, Churu, Sriganganagar, Nagaur, Jalore, Sikar, Jaisalmer, Bikaner, Jaipur, Jhunjhunu and Alwar districts.

\section{Nitrogen}

Nitrogen plays an important role in synthesis of chlorophyll and amino acid, which contributes to the building units of protein and thus the growth of plants. Insufficient nitrogen may reduce yield drastically and deteriorates the quality of produce. Cluster bean being a legume crop which has the capacity to fix atmospheric nitrogen by its effective root nodules the major part of nitrogen is met through rhizobium present in the root nodules hence, crop does not require additional nitrogen for its initial growth and development stage. The nitrogen application increased crude protein, crude fibre contents, ash percentage, carbohydrates, and leaf area per plant, dry matter and green fodder yield of cluster bean cultivars (Ayub et al., 2010).

\section{Phosphorus}

Phosphorus is the second most important nutrient that must be added to the soil to maintain plant growth and sustain crop yield (Singh et al., 2000).Phosphorus plays a vital role in photosynthesis, respiration, energy storage, cell elongation and improves the quality of crops. Deficient plants may have thin, erect and spindly stems and leaves turn into bluish-green colour. Phosphorus is an essential constituent of majority of enzymes, which are of great importance in the transformation of energy, in carbohydrate metabolism, in fat metabolism and also in respiration of plants. It stimulates early root development and growth and there by helps to establish seedlings quickly. It enhances the activity of rhizobium and increased the formation of root nodules. Thus, it helps in fixing more of atmosphere nitrogen in root nodules.Hand book of Agriculture by ICAR, (2010).

\section{Potassium}

The potassium is the 3rd most important essential nutrient after nitrogen and phosphorus. The potassium activates more than 60 enzymes and enzymatically catalyzes the system involved in photosynthesis, metabolism and translocation of carbohydrates and proteins, membrane permeability, stomatal regulation and water utilization. Other benefits ascribed to $\mathrm{K}$ include resistance of plants against pests, disease and stresses caused by drought, frost, salinity, sodicity and in assuring improved crop quality characteristics (Kherawat et al., 2013).

\section{Farm yard manure}

The organic manure like FYM is the oldest and cheapest source or nutrient being popular from the ancient times. Application of FYM on field enrich the soil fertility is an old practice unlike chemical fertilizers which contain only one, two or three plant nutrients. FYM seems to act directly for increasing the crop yields either by acceleration of respiratory process with increasing cell permeability and hormonal growth action or by combination of all these processes. FYM provides plants both macro and micronutrients. It supplies nitrogen, phosphorus, potassium and micronutrients like Fe, S, Mo, Zn etc. in available from to the plants through biological decomposition and improves physical-chemical properties of soil such as aggregation, aeration, permeability, 
water holding capacity, slow release of nutrients, increasing in cation exchange capacity, stimulation of soil flora and fauna etc. A well decomposed FYM contains $0.5 \% \mathrm{~N}, 0.2 \% \mathrm{P} 2 \mathrm{O} 5$ and $0.5 \% \mathrm{~K} 2 \mathrm{O}$. Hand book of Agriculture by ICAR, (2010).

\section{Rhizobium}

The use of biofertilizers are more eco-friendly in nature. They can play a significant role in fixing atmospheric nitrogen biofertilizers enrich soil fertility and improves soil fertility. Of these biofertilizers, Rhizobium inoculants specific for different leguminous crop is the most important in India. The largest contribution of biological nitrogen fixation to agriculture is derived from the symbiosis between legumes and Rhizobium species.

\section{Materials and Methods}

A field experiment was conducted on research farm of department of Soil Science and, Agricultural Chemistry. SHUATS Allahabad, (U.P.) India. The soil of experimental area falls in order Inceptisol and alluvial in nature. The design applied for statistical analysis was carried out with $3 \times 2 \times 2$ factorial randomized block design having three factors with three levels of NPK @ 0,50, and 100\% ha ${ }^{-1}$, two levels of FYM 0 and $100 \% \mathrm{ha}^{-1}$ and two level of rhizobium 0 and $100 \% \mathrm{ha}^{-1}$ respectively.

\section{Physical and chemical analysis}

The soil samples were preserved in polythene bags for analysis of physical and chemical properties.

\section{Physical analysis}

The physical analysis was done with the help of Bouyoucous Hydrometer method for textural class and copper cylinder method for bulk and particle density. The results of analysis are as under.

\section{Chemical analysis}

The chemical analysis of pre sowing was done for $\mathrm{pH}, \mathrm{EC}$, available nitrogen, phosphorus, potassium, and organic carbon (\%). The results and various methods employed are represented under the following table.

\section{Results and Discussion}

The Table 3 shows the interaction effects of NPK and FYM are generally influenced physical and chemical properties of postharvest soil.

\section{Physical properties}

The interaction effects of NPK, and FYM on bulk density (Mg m-3) and particle density (Mg m-3) was non- significant. The maximum particle density and bulk density after crop harvest soil was recorded as $2.66 \mathrm{Mg} \mathrm{m}-3,1.14 \mathrm{Mg} \mathrm{m}-3$ respectively inT0(L0+N0)@0\%NPK ha ${ }^{-1}+@ 0 \% \mathrm{FYM} \mathrm{ha}^{-1}$.

\section{Chemical properties of post -harvest soil}

During the course of study, it was observed that the highest $\mathrm{pH}$ was recorded in 7.35 (T0(L0+N0)@0\%NPK ha ${ }^{-1}+@ 0 F Y M h^{-1}$ ) and the lowest of 6.89 was recorded with the application of treatment T8-(L2+N2) @ $100 \% \mathrm{NPK} \mathrm{ha}^{-1}+@ 10 \mathrm{qFYM} \mathrm{ha}{ }^{-1}$. If we compare the $\mathrm{pH}$ of pre sowing soil sample which was 7.40 with that of after crop harvest soil, there was decrease in $\mathrm{pH}$ after crop harvest. Increasing dose of NPK and FYM slightly decrease $\mathrm{pH}$ of the post-harvest soil. The decrease in $\mathrm{pH}$ might be due to higher growth of crops as respiration is more. Respiration evolves carbon dioxide and reacts with water to form carbonic acid in soil. 
The electric conductivity $\left(\mathrm{dSm}^{-1}\right)$, organic carbon (\%), available nitrogen, phosphorus and potassium $\left(\mathrm{kg} \mathrm{ha}^{-1}\right)$ was increase of soil after crop harvests. The chemical properties were significantly affected by different treatment combination of NPK and FYM.

Table.1 Treatment details

\begin{tabular}{|c|c|c|}
\hline Treatment & Treatment Combination & Symbol \\
\hline $\mathrm{T}_{0}$ & $\mathrm{~N}_{0} \mathrm{P}_{0} \mathrm{~K}_{0} \mathrm{Kg} \mathrm{ha}^{-1}+\mathrm{FYM} @ 0 \mathrm{tha}^{-1}+$ Rhizobium @0 $\mathrm{g} \mathrm{Kg}^{-1}$ seed & $\mathrm{L}_{0} \mathrm{~F}_{0} \mathrm{Z}_{0}$ \\
\hline $\mathrm{T}_{1}$ & $\mathrm{~N}_{0} \mathrm{P}_{0} \mathrm{~K}_{0} \mathrm{Kg} \mathrm{ha}^{-1}+\mathrm{FYM} @ 0 \mathrm{tha}^{-1}+$ Rhizobium @ $20 \mathrm{~g} \mathrm{Kg}^{-1}$ seed & $\mathrm{L}_{0} \mathrm{~F}_{0} \mathrm{Z}_{1}$ \\
\hline $\mathrm{T}_{2}$ & $\mathrm{~N}_{0} \mathrm{P}_{0} \mathrm{~K}_{0} \mathrm{Kg} \mathrm{ha}^{-1}+\mathrm{FYM} @ 10 \mathrm{tha}^{-1}+$ Rhizobium $@ 0 \mathrm{~g} \mathrm{Kg}^{-1}$ seed & $\mathrm{L}_{0} \mathrm{~F}_{1} \mathrm{Z}_{0}$ \\
\hline $\mathrm{T}_{3}$ & $\mathrm{~N}_{0} \mathrm{P}_{0} \mathrm{~K}_{0} \mathrm{Kg} \mathrm{ha}^{-1}+\mathrm{FYM} @ 10 \mathrm{tha}^{-1}+$ Rhizobium @ $20 \mathrm{~g} \mathrm{Kg}^{-1}$ seed & $\mathrm{L}_{0} \mathrm{~F}_{1} \mathrm{Z}_{1}$ \\
\hline $\mathrm{T}_{4}$ & $\mathrm{~N}_{10} \mathrm{P}_{20} \mathrm{~K}_{0} \mathrm{Kg} \mathrm{ha}^{-1}+\mathrm{FYM} @ 0 \mathrm{tha}^{-1}+$ Rhizobium @ $0 \mathrm{~g} \mathrm{Kg}^{-1}$ seed & $\mathrm{L}_{1} \mathrm{~F}_{0} \mathrm{Z}_{0}$ \\
\hline $\mathrm{T}_{5}$ & $\mathrm{~N}_{10} \mathrm{P}_{20} \mathrm{~K}_{0} \mathrm{Kg} \mathrm{ha}^{-1}+\mathrm{FYM} @ 0 \mathrm{tha}^{-1}+$ Rhizobium @ $20 \mathrm{~g} \mathrm{Kg}^{-1}$ seed & $\mathrm{L}_{1} \mathrm{~F}_{0} \mathrm{Z}_{1}$ \\
\hline $\mathrm{T}_{6}$ & $\mathrm{~N}_{10} \mathrm{P}_{20} \mathrm{~K}_{0} \mathrm{Kg} \mathrm{ha}^{-1}+\mathrm{FYM} @ 10 \mathrm{tha}^{-1}+$ Rhizobium @ $0 \mathrm{~g} \mathrm{Kg}^{-1}$ seed & $\mathrm{L}_{1} \mathrm{~F}_{1} \mathrm{Z}_{0}$ \\
\hline $\mathrm{T}_{7}$ & $\mathrm{~N}_{10} \mathrm{P}_{20} \mathrm{~K}_{0} \mathrm{Kg} \mathrm{ha}^{-1}+\mathrm{FYM} @ 10 \mathrm{tha}^{-1}+$ Rhizobium $@ 20 \mathrm{~g} \mathrm{Kg}^{-1}$ seed & $\mathrm{L}_{1} \mathrm{~F}_{1} \mathrm{Z}_{1}$ \\
\hline $\mathrm{T}_{8}$ & $\mathrm{~N}_{20} \mathrm{P}_{40} \mathrm{~K}_{0} \mathrm{Kg} \mathrm{ha}^{-1}+\mathrm{FYM} @ 0 \mathrm{tha}^{-1}+$ Rhizobium @0 $\mathrm{g} \mathrm{Kg}^{-1}$ seed & $\mathrm{L}_{2} \mathrm{~F}_{0} \mathrm{Z}_{0}$ \\
\hline $\mathrm{T}_{9}$ & $\mathrm{~N}_{20} \mathrm{P}_{40} \mathrm{~K}_{0} \mathrm{Kg} \mathrm{ha}^{-1}+\mathrm{FYM} @ 0 \mathrm{tha}^{-1}+$ Rhizobium @ $20 \mathrm{~g} \mathrm{Kg}^{-1}$ seed & $\mathrm{L}_{2} \mathrm{~F}_{0} \mathrm{Z}_{1}$ \\
\hline $\mathrm{T}_{10}$ & $\mathrm{~N}_{20} \mathrm{P}_{40} \mathrm{~K}_{0} \mathrm{Kg} \mathrm{ha}^{-1}+\mathrm{FYM} @ 10 \mathrm{tha}^{-1}+$ Rhizobium $@ 0 \mathrm{~g} \mathrm{Kg}^{-1}$ seed & $\mathrm{L}_{2} \mathrm{~F}_{1} \mathrm{Z}_{0}$ \\
\hline $\mathrm{T}_{11}$ & $\mathrm{~N}_{20} \mathrm{P}_{40} \mathrm{~K}_{0} \mathrm{Kg} \mathrm{ha}^{-1}+\mathrm{FYM} @ 10 \mathrm{tha}^{-1}+$ Rhizobium @ $20 \mathrm{~g} \mathrm{Kg}^{-1}$ seed & $\mathrm{L}_{2} \mathrm{~F}_{1} \mathrm{Z}_{1}$ \\
\hline
\end{tabular}

Table.2 Physical analysis of pre sowing soil samples

\begin{tabular}{lll}
\hline \multicolumn{1}{c}{ Particulars } & \multicolumn{1}{c}{ Method employed } & Result \\
\hline & & \\
Sand (\%) & Bouyoucos Hydrometer method (1927) & 62.25 \\
Silt (\%) & & 24.52 \\
Clay (\%) & & 13.23 \\
Textural class & Bouyoucous Hydrometer & Sandy loam \\
& method Bouyoucous (1927) & \\
Soil Colour & Munsell colour chart & \\
Dry Soil & & Pale brown \\
Wet Soil & & Olive brown \\
Bulk density $\left(\mathrm{Mg} \mathrm{m}^{-3}\right)$ & Black (1965) & 1.41 \\
Particle density $\left(\mathrm{Mg} \mathrm{m}^{-3}\right)$ & Black (1965) & 2.50 \\
& & \\
\hline
\end{tabular}


Table.4 Response of effect of different levels of NPK, FYM and Rhizobiumin post-harvest soil properties of cluster bean (Cyamopsis tetragonoloba L.) cv. Pusa Sadabahar

\begin{tabular}{|c|c|c|c|c|c|c|c|c|}
\hline $\begin{array}{l}\text { Treatment } \\
\text { combination }\end{array}$ & $\begin{array}{l}\text { Bd } \\
(\mathrm{Mg} \\
\left.\mathrm{m}^{-3}\right)\end{array}$ & $\begin{array}{l}\text { Pd } \\
(\mathrm{Mg} \\
\left.\mathrm{m}^{-3}\right)\end{array}$ & $\begin{array}{l}\text { pH } \\
(1: 2 w / v)\end{array}$ & $\begin{array}{l}\mathrm{EC} \\
\left(\mathrm{dSm}^{-1}\right)\end{array}$ & $\begin{array}{l}\text { O.C. } \\
(\%)\end{array}$ & $\begin{array}{l}\text { N (kg } \\
\left.\text { ha }^{-1}\right)\end{array}$ & $\begin{array}{l}\mathbf{P}_{2} \mathrm{O} \\
\left.\mathrm{ha}^{-1}\right)\end{array}$ & $\begin{array}{l}\mathrm{K}_{2} \mathrm{O} \\
\left(\mathrm{kg}^{-1}\right. \\
\left.\mathrm{ha}^{-1}\right)\end{array}$ \\
\hline$\left(\mathrm{I}_{0}+\mathrm{F}_{0}+\mathrm{R}_{0}\right)$ & 1.14 & 2.24 & 7.35 & 0.192 & 0.62 & 275.09 & 21.89 & 131.67 \\
\hline$\left(\mathrm{I}_{0}+\mathrm{F}_{0}+\mathrm{R}_{1}\right)$ & 1.09 & 2.33 & 7.15 & 0.195 & 0.66 & 294.29 & 23.09 & 146.64 \\
\hline$\left(\mathrm{I}_{0}+\mathrm{F}_{1}+\mathrm{R}_{0}\right)$ & 1.13 & 2.33 & 7.32 & 0.205 & 0.69 & 288.00 & 23.69 & 142.89 \\
\hline$\left(\mathrm{I}_{0}+\mathrm{F}_{1}+\mathrm{R}_{1}\right)$ & 1.10 & 2.41 & 7.12 & 0.208 & 0.73 & 296.38 & 25.18 & 154.12 \\
\hline$\left(\mathrm{I}_{1}+\mathrm{F}_{0}+\mathrm{R}_{0}\right)$ & 1.10 & 2.44 & 7.09 & 0.223 & 0.72 & 297.42 & 26.38 & 157.86 \\
\hline$\left(\mathrm{I}_{\mathrm{I}}+\mathrm{F}_{0}+\mathrm{R}_{1}\right)$ & 1.11 & 2.45 & 7.02 & 0.225 & 0.76 & 312.10 & 27.13 & 169.09 \\
\hline$\left(\mathrm{I}_{1}+\mathrm{F}_{1}+\mathrm{R}_{0}\right)$ & 1.09 & 2.54 & 7.09 & 0.235 & 0.78 & 313.77 & 29.00 & 172.83 \\
\hline$\left(\mathrm{I}_{1}+\mathrm{F}_{1}+\mathrm{R}_{1}\right)$ & 1.09 & 2.54 & 7.09 & 0.235 & 0.81 & 314.20 & 29.08 & 180.55 \\
\hline$\left(\mathrm{I}_{2}+\mathrm{F}_{0}+\mathrm{R}_{0}\right)$ & 1.09 & 2.63 & 7.05 & 0.235 & 0.81 & 316.53 & 30.57 & 187.15 \\
\hline$\left(\mathrm{I}_{2}+\mathrm{F}_{0}+\mathrm{R}_{1}\right)$ & 1.07 & 2.63 & 7.02 & 0.245 & 0.84 & 318.82 & 31.77 & 196.25 \\
\hline$\left(\mathrm{I}_{2}+\mathrm{F}_{1}+\mathrm{R}_{0}\right)$ & 1.07 & 2.63 & 6.99 & 0.245 & 0.86 & 320.48 & 33.87 & 206.52 \\
\hline$\left(\mathrm{I}_{2}+\mathrm{F}_{1}+\mathrm{R}_{1}\right)$ & 1.05 & 2.66 & 6.89 & 0.255 & 0.88 & 334.12 & 34.76 & 214.74 \\
\hline F- test & NS & $\mathrm{NS}$ & NS & $\mathrm{NS}$ & $\mathrm{S}$ & $\mathrm{S}$ & $\mathrm{S}$ & $\mathrm{S}$ \\
\hline S. Em $( \pm)$ & 0.24 & 0.24 & 0.38 & 0.24 & 0.0004 & 1.71 & 0.13 & 0.55 \\
\hline C. D. at $5 \%$ & 0.48 & 0.49 & 0.77 & 0.49 & 0.0008 & 3.47 & 0.27 & 1.11 \\
\hline
\end{tabular}

Fig.1 Effect of different levels of NPK FYM and Rhizobium on

Post-harvest soil chemical properties of cluster bean

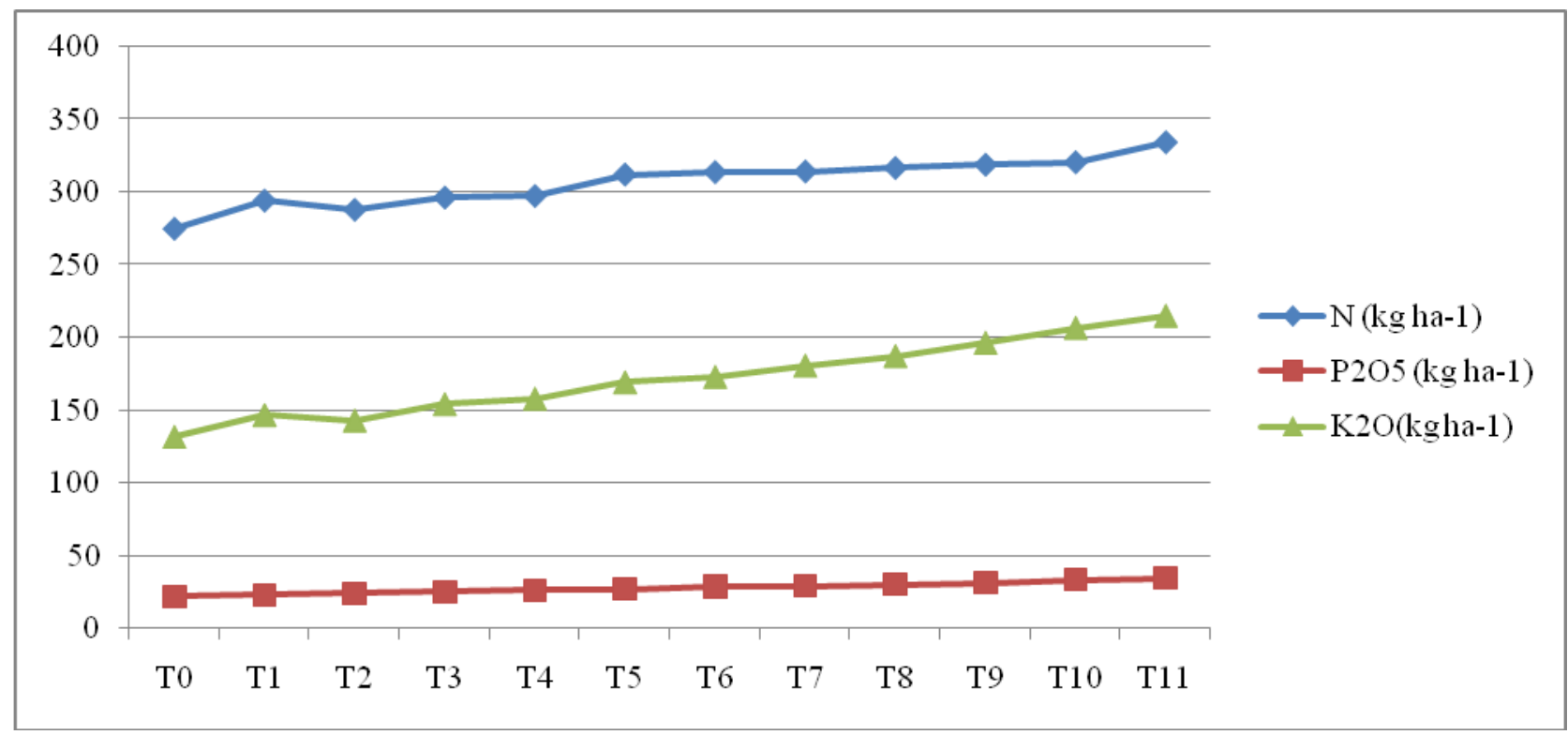


Fig.2 Effect of different levels of NPK FYM and Rhizobium on

Post-harvest soil physical properties of cluster bean

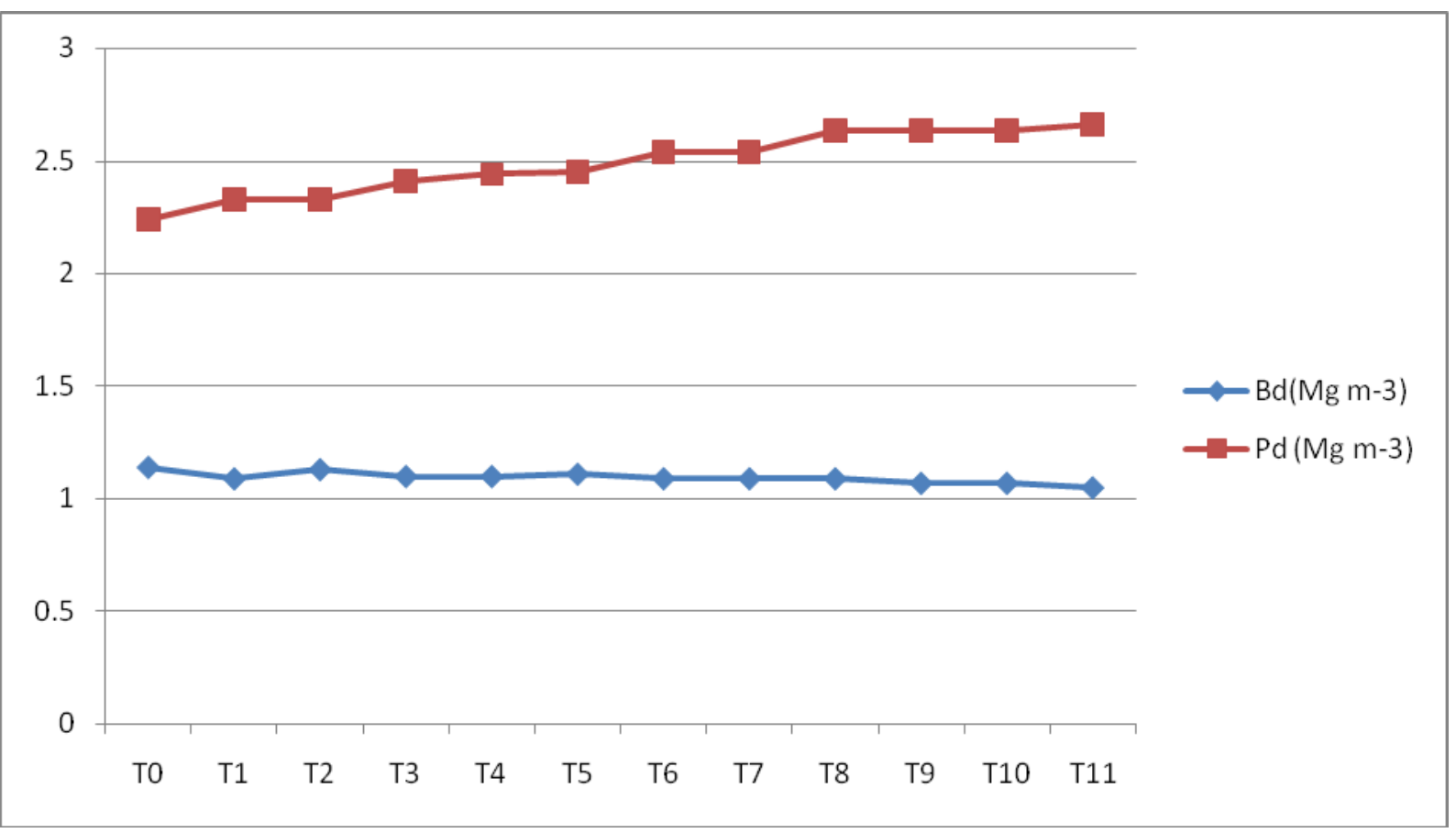

Fig.3 Effect of different levels of NPK FYM and Rhizobium on

Post-harvest soil chemical properties of cluster bean

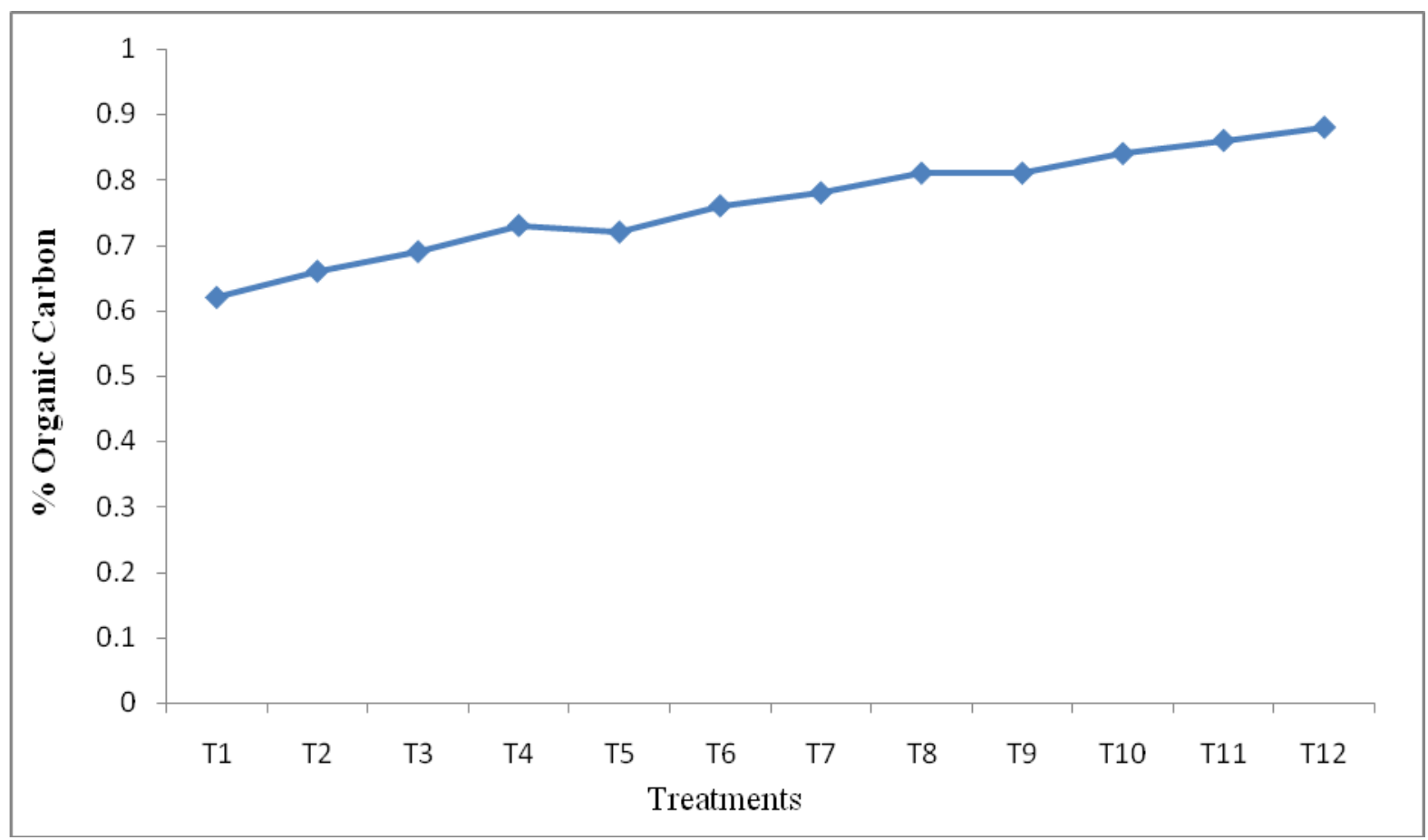


Table.3 Chemical analysis of pre sowing soil samples

\begin{tabular}{lll}
\hline \multicolumn{1}{c}{ Parameters } & \multicolumn{1}{c}{ Method employed } & Result \\
\hline Soil $\mathrm{pH}(1: 2)$ & Digital $\mathrm{pH}$ meter (Jackson 1958) & 7.40 \\
Soil EC( $\left(\mathrm{dSm}^{-1}\right)$ & Digital EC meter(Wilcox 1950) & 0.31 \\
Organic carbon $(\%)$ & Walkley and Black (1947) & 0.48 \\
Available nitrogen $\left(\mathrm{Kg} \mathrm{ha}^{-1}\right)$ & Kjeldhal Method (Subbaih and Asija, 1956) & 260.06 \\
Available phosphorus $\left(\mathrm{Kg} \mathrm{ha}^{-1}\right)$ & Colorimetric method (Olsen et al., 1954) & 23.30 \\
Available potassium $\left(\mathrm{Kg} \mathrm{ha}^{-1}\right)$ & Flame photometric method (Toth and & 135.60 \\
& Prince, 1949) & \\
\hline
\end{tabular}

The effect of NPK fertilizer on organic carbon (\%), available nitrogen, phosphorus, potassium $\left(\mathrm{kg} \mathrm{ha}^{-1}\right)$, electric conductivity $\left(\mathrm{dSm}^{-1}\right)$ significant the maximum chemical propertiesof after crop harvest soil was recorded electric conductivity $\left(\mathrm{dSm}^{-1}\right)$, organic carbon (\%), available nitrogen, phosphorus, potassium $\left(\mathrm{kg} \mathrm{ha}^{-1}\right) 0.255,0.88$, 334.12, 34.76, 214.74 respectively. available electric conductivity $\left(\mathrm{dSm}^{-1}\right)$ was found nonsignificant and available organic carbon (\%), nitrogen, phosphorus, potassium $\left(\mathrm{kg} \mathrm{ha}^{-1}\right)$ found to be significant.

It was concluded from trial that the various level of NPK + FYM and Rhizobium used in the experiment, the treatment combination T11-(I2+V2+R1) @100\%NPK ha ${ }^{-1}+$ @ FYM $10 \mathrm{t} \mathrm{ha}^{-1}+$ Rhizobium @ 20 g/ Kg seed was found to be the best treatment gave highest benefit of 100438with highest cost benefit ratio 1:2.85 for cluster bean it could be recommended for profitable production of cluster bean (Cyamopsis tetragonoloba L.) Var. pusa Sadabahar and good for soil physical and chemical properties. Integrated nutrient management is better for soil health and cluster bean production.

\section{Acknowledgement}

Authors are sincerely thankful to the Hon'ble Prof. (Dr.) Gautam Ghosh, Head of department (Agronomy), Sam Higginbottom University of Agriculture, Technology and
Sciences Allahabad, U. P., for providing all necessary facilities.

\section{References}

Anonymous 2010-11. Rajasthan Agriculture Statistics at a glance. Department of Agriculture Government of Rajasthan.

Ayub, M., Khalid, M., Tariq, M., Nadeem, M.A., and Naeem, M. 2011. Effect of different seeding densities and nitrogen levels on growth, forage yield and quality attributes of Cluster bean (Cyamoposis tetragonoloba Tuab.) J. Agri. Technol., Vol. 7 (5): 1409-1416.

Black, C.A. 1965. Methods of soil analysis Vol. I. Am. Soc. Agron. Madison, Wisconsin, U.S.A.

Brady, N.C. and Weil, R.R. 1996. The nature and properties of soils (11th ed.). Prentice Hall, New York.

Buoyoucos, G.J. 1952. A recalibration of the hydrometer method for making mechanical analysis of soil, 43, 434.

Fisher, R.A. 1950. Technique of analysis of variance, Handbook of Agricultural statistics, B-29- 110.

Jackson, M.L. 1958. Soil chemical analysis, Prentice Hall, Inc, Englewood Cliffe, N.J.

Jaiswal P.C. 2006. Soil, Water and plant Analysis, Manual Practical.

Kherawat, B.S., Munna Lal, Agarwal, M., Yadav, H.K. And Kumar, S. 2013. Effect of applied potassium and manganese on yield and uptake of nutrients by cluster bean (Cyamopsis tetragonoloba). $J$. Agric. Physics, 13(1): 22-26. 
Muthuaval, P.C., Udayasooriyan. R., Natesan. P.P. and Ramaswami.1998. Introduction to soil analysis, Tamilnadu Agriculture University, Coimbatore-641002.

Olsen, S.R., Cole, C.V., Watnahe, F.S. and Dean, L.A. 1954. Estimation of available phosphorus in soils by extraction with sodium bicarbonate U.S. Deptt. Agr. Circ. 939.

Panda, S.C. 2011. Handbook of agriculture PP; 310-321.

Toth, S.J. and A.L. Prince. 1949. Estimation of cation exchange capacity and exchangeable $\mathrm{Ca}, \mathrm{K}$ and $\mathrm{Na}$ content of soil by flame photometer technique. Soil Sci., 67: 439-445.

Walkey, A. and Black, I.A. 1947. Critical examination of rapid method for determining organic carbon in soils, effect of variance in digestion conditions and of inorganic soil constituents. Soil Sci., pp.632: 251.

Wilcox, L.V. 1950. Electrical conductivity, Amer. Water works Assoc. J., 42: pp 775776.

\section{How to cite this article:}

Asha, Narendra Swaroop and Tarence Thomas. 2017. Response of integrated nutrient management on soil properties, growth and yield of cluster bean (Cyamopsis tetragonoloba 1.) Cv. Pusa sadabahar. Int.J.Curr.Microbiol.App.Sci. 6(5): 2684-2691. doi: https://doi.org/10.20546/ijcmas.2017.605.301 